Tadeusz Kudtacz

Cracow University of Economics e-mail: kudlaczt@uek.krakow.pl

Piotr Lityński

Cracow University of Economics e-mail: litynskp@uek.krakow.pl

\title{
PROJECTIONS OF FINANCIAL IMPLICATIONS OF PLANNING DECISIONS: AN EXAMPLE OF THE CRACOW DEVELOPMENT STRATEGY PROJECT FOR 2030
}

\begin{abstract}
Estimating the financial implications of territorial development plans is a complex task. That complexity is a derivative of: detailed planning decisions, planning a time horizon, and the multidimensional category of territorial development. Referring to the above operationalization of methods of projections, the rapidly increasing difficulties in the conceptualization of analytical methods is visible as well as the availability of the necessary informative material. For these reasons, the development strategies of many units have no estimates giving answers to basic questions of: how much the implementation of a strategy will cost? what financial potential of sources is, what can make it possible to involve the strategy implementation? These are the issues and questions targeted in the article. The empirical exemplification of the results is the project, currently being updated - The Cracow Development Strategy 2030. The article consists of three chapters and conclusions. These chapters substantively develop: (-) the issue of the financial implications of planning decisions, (-) a proposal for a methodology for estimating financial resources for the strategy implementation and estimating the financial potential of its implementation, (-) realization of the proposed methodology for the project of SRK 2030. Among the results of the research it can be pointed out, that the expenditures for the implementation of CDS will reach 11 billion PLN, while the financial potential fluctuates around 16 billion PLN.
\end{abstract}

Keywords: development strategy, expenditures, estimating, financing sources

\section{Streszczenie}

\section{Szacowanie następstw finansowych decyzji planistycznych: Przykład Strategii Rozwoju Krakowa do 2030 roku}

Szacowanie następstw finansowych ustaleń planu rozwoju jednostki terytorialnej jest przedsięwzięciem złożonym. Owa złożoność jest pochodną w szczegółowości: ustaleń planistycznych, horyzontu czasowego planu, wielowymiarowości kategorii: rozwój jednostki terytorialnej. 
Odnosząc powyższe do operacjonalizacji metodycznej szacunków ex-ante, można zauważyć szybko narastające trudności w konceptualizacji metod analitycznych i dostępności niezbędnego materiału informacyjnego. Z tych właśnie względów w strategiach rozwoju wielu jednostek terytorialnych brak szacunków dających odpowiedź na podstawowe wszak pytania: jaka jest wielkość koniecznych nakładów finansowych na realizację strategii? jaki jest potencjał finansowy źródeł możliwych do zaangażowania dla realizacji strategii? Te właśnie zagadnienia i pytania stały się celami prezentowanego opracowania. Empiryczną egzemplifikacją rozważań jest aktualizowana Strategia Rozwoju Krakowa. Artykuł składa się z trzech rozdziałów merytorycznych oraz wniosków. Rozdziały merytoryczne rozwijają: (-) problematykę następstw finansowych ustaleń planistycznych; (-) propozycję metodyki szacowania nakładów finansowych na realizację strategii oraz szacowania potencjału finansowego jej realizacji; (-) implementację propozycji metodycznych na przykładzie Strategii Rozwoju Krakowa. Wśród rezultatów badań wskazać można, że nakłady finansowe na realizację Strategii Krakowa oscylować mogą w granicach $11 \mathrm{mld} \mathrm{zł,} \mathrm{natomiast} \mathrm{potencjał} \mathrm{finansowy,} \mathrm{po} \mathrm{który} \mathrm{władze} \mathrm{lokalne}$ mogą sięgnąć, wynosi 16 mld zł.

Słowa kluczowe: strategia rozwoju, wydatki, szacowanie, źródła finansowania

\section{Introduction}

A significant step in the preparation of the activities of public authorities is to identify the financial consequences of these actions. This is understandable. However, in the case of the management processes of social and economic development, an opportunity to integrate to the management processes a unit specifying the financial implications of future development activities, is ever so difficult. These difficulties are associated with the complexity of the processes' of long-term socio-economic development, resulting in methodological complexity in projections of the financial implications of development activities.

Honoring the above, this article adopted the goal of conceptualization and operationalization of methods for estimating financial implications of future action by public authorities in the field of socio-economic development.

At the same time, it should be noted that financial projections are based on certain assumptions and are encumbered by uncertainty - as the horizon of estimates is the year 2030 - which plays an important role in the management of city development. Financial projections provide a preparatory function for the implementation of the Strategy. Entities involved in the implementation of the management process in pursuit of the objectives of the Strategy must choose how to achieve them, taking into account the conditions under which they must operate - including financial. Thus, the function of financial projections presented in the article may constitute a preparation for the implementation of the Strategy.

The exemplification of the method is currently being updated in the project of The Cracow Development Strategy 2030 (CDS 2030).

Presented in the article financial projections are the authors' own calculations using a variety of statistical and econometric techniques. Data sources were: Central Statistical Office (CSO), Ministry of Finance (MF), Cracow City Hall. 


\section{The financial consequences of planning decisions in the light of various types of development plans of territorial units}

The considerations presented in this article apply to plans/programs of development units. This is worth emphasizing because this category of plans, in the context of the undertaken subject, differs significantly from the plans drawn up for private companies. The differences relate primarily to the complexity of the projections made given the multidimensionality of the category of territorial development unit (city, region).

The dominant elements of each plan are goals that the entity intends to achieve in the assumed time horizon. Their detail, including the concreteness of recognition, is a derivative of the latter, and so the assumption of time perspective of the plan implementation arrangement. These issues are obvious, but recalling them justifies the taken article subject. Problems of estimating the financial implications of making planning decisions depends directly on the types of plans designated by the horizon of implementation. Both short-term and medium-term plans partly hold a detailed and specific development objective and do not raise general difficulties in the financial dimension of their effects. It is possible, especially in regard to short-term plans, that the application of methodology directly values the necessary expenditures and expected results. Of course, the complicating factor for the plans within this category is that the analysis must relate to the future, and so they have to be hypothetical in nature due to the advance received from the need of assumptions regarding valuation parameters carried out. The situation begins to complicate strongly with increasing the time horizon of plans. If we assume that in determining the financial implications of the implementation of goals is dominated by the principle of the greatest reliability of the results obtained, the issue is presented graphically and recognized in Figure 1.

The complexity of estimating the financial consequences of adopted arrangements of development plans as extending the horizon of the plan, is increasing at the rate of a non-linear rising. This is due to the fact that the discussed relationship as extending the horizon of predicting is shaped not only by the necessary decrease of detail and concreteness of the goals, but also by the quickly rising difficulties in identifying hypothetical circumstances in which the implemented and accepted goals will arise.

The most complex action is the financial assessment of the findings of plans that recognize the strategic directions of developmental units. This is due to two major features of development strategy. Firstly, a long perspective prediction, dictated the need for significant changes in the design development of a territorial unit (and it is not possible to achieve in short term). Secondly, the necessity of selecting the goals, focusing on interventions that may determine the success, and therefore trigger (reinforcement) the driving forces of development. As a result, a significant decrease in specifically accepted findings follows, and thus a need to look for specific methodological approaches in valuation of the impacts. 


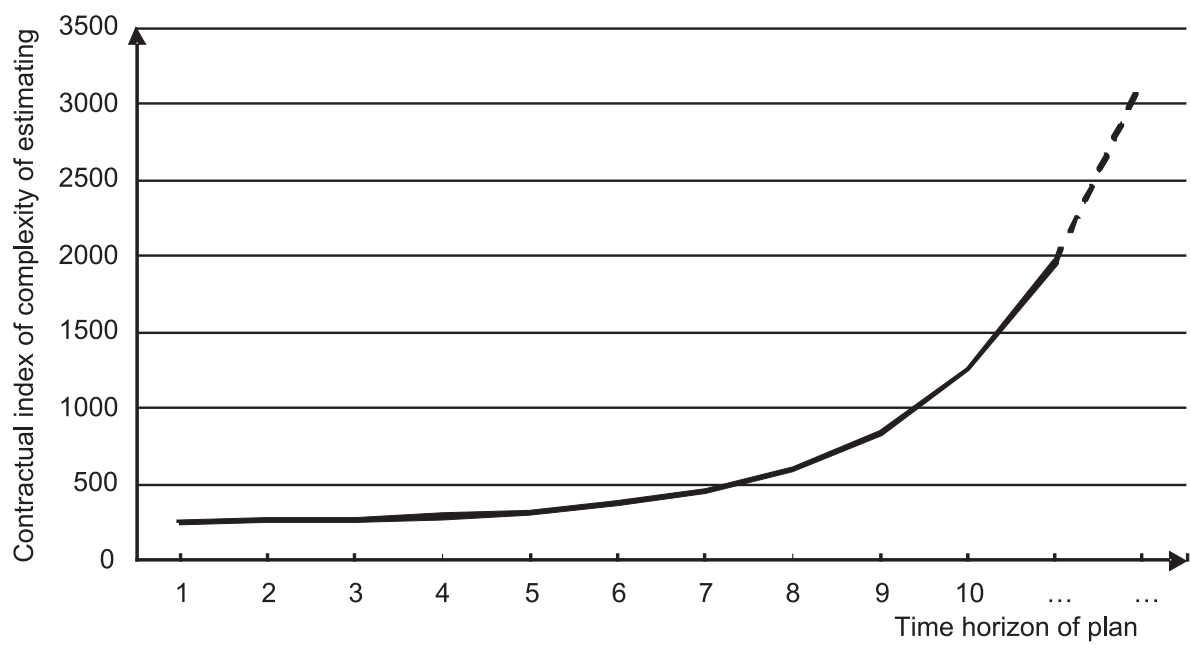

Figure 1. Changes in the complexity of projecting the financial implications of the development plans of territorial units

Source: own work

The potential financial consequences of the adopted plan arrangements have two basic dimensions. One of them is appropriately evaluated achievements of development. The strategic programs are extremely difficult for accounting analyzes not only for reasons previously presented, but also because of the multiplier effects [Markowska, Sobczak, 2006: 280-281] and multidirectional connections in the set of potential components of development (e.g. the synergy and conflict). The second dimension is the need to incur the expenditures concerning the actions declared by authorities to trigger specific stimulators of growth or reduction of identified barriers, thus creating conditions for accelerated development.

Referring the above to strategic development plans of territorial units, it is not difficult to note that the first group refers to the aftermath purposes out of a vision of development, while the second is related to the mission of development. This observation is essential and in practice yet not always followed by the principle of clear distinction hierarchy of structural development objectives. This deriving from the structure of the interventions' assumed directions. The situation, when a given level of the tree targets, displays findings belonging to both structures, thus highly limiting reliable inferences about the financial implications of the plans' findings.

\section{Method}

For the realization of the objective two research tasks were proposed, i.e.:

1) estimate of the financial outlays necessary for the implementation of the objectives of the project of CDS 2030; 
2) assessment of the financial potential that can be engaged to achieve the objectives of the project of CDS 2030, taking into account different sources.

These tasks, on the one hand, are to answer the question of a rough cost and financial resources to implement the Strategy, on the other hand, if the available financial resources are in fact able to cover the necessary financial expenditures.

\section{I. The scope of financial outlays for the implementation of the project of CDS 2030}

Projections were based on a draft of CDS 2030 (version of 2016-05-05), specifically the projection part of the document including a set of objectives and actions. The hierarchy of objectives is presented in Figure 2. The estimates were calculated for key actions (highest level of detail), 145 of which were presented, these are then summarized in operational objectives, and further strategic objectives.

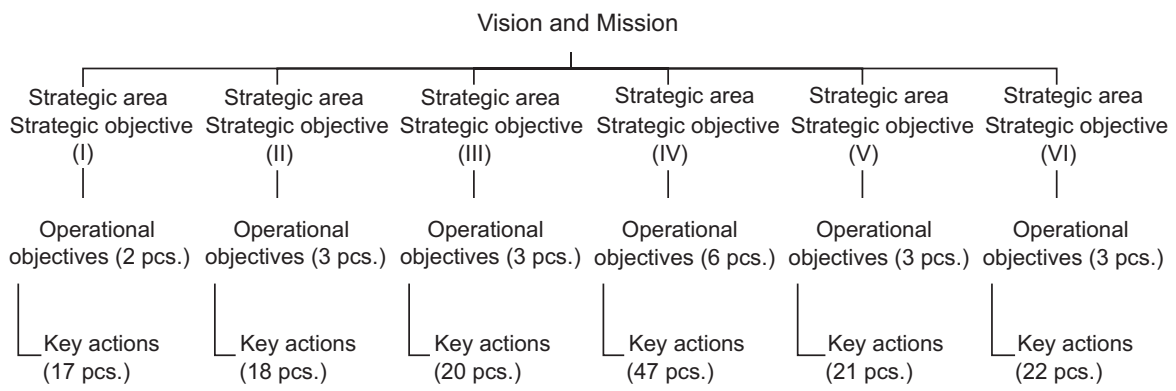

Figure 2. Schematic structure of objectives in the project of CDS 2030

Source: own work

Since the key actions are the formulation of which, despite the most operational character in the project of CDS 2030, differ in the level of detail, and most remain at a relatively high level of generality, thus the article proposed a methodically varied assessment to each of the key actions. The dominant techniques are based on assumptions of desk research and analog forecasting. This means that each of the key actions was estimated individually using the most suited methodological approach, dictated by the desire for the highest precision of the estimates. In the case of the use of desk research techniques, the choice of the base of forecasting, is a program based on the predicted phenomenon, first indicated in the project of CDS 2030 catalogue of Policies/Programmes and Strategic Projects. While the key actions which do not have coverage in developed financial plans by the City require the use of techniques based on analog forecasting. Therefore, with respect to analog forecasting, conducted analysis was guided by the criteria of satisfactory similarities, which consist of the place criterion and the scope criterion. The place criterion concerns the link of the base of forecasting with 
Cracow, e.g.: a program implemented in the past by the City of Cracow authorities. The scope criterion is related to the range between the scope of the basis of forecasting and the scope of the projected key action. The scope of the projected key action was determined heuristically by referencing the key actions to an operating objective with the use of the description of operational objectives, which is stated in the draft of CDS 2030. In general, the algorithm for estimating included: (1) the reference of the tasks of the program which is the basis of forecasting to the scope of the CDS key actions and on this basis; (2) the estimate of average annual expenditure of implementation of the core forecasting in terms of content corresponding to the range of projected key action of CDS; and subsequently (3) multiplying the average annual amounts over a number of years of the CDS project.

All estimates are presented in current prices. The presentation of the forecasted estimates guideline the macroeconomic assumptions for the needs of long-term financial forecasts of local government units used (2015).

\subsection{The financial potential for the implementation of the project of CDS 2030}

The budget of a city is crucial in financing the local development, however, an important role is played by external sources, e.g. EU funds and the national budget. At the same time in the draft of the Strategy there are actions whose implementation will be derived from the activity of entities external to the City Authorities (example: private companies) and the Authority will play only a coordinating role. Therefore, it is reasonable also to recognize future investment in the private sector [Hołuj, Hołuj, 2010: 62-63]. In this light, the financial potential of the project of CDS 2030 was presented in the following 5 groups of financing sources:

\section{A. The Budget of the City of Cracow}

The carried out analysis were based on the cumulative amounts of capital expenditures of the annual budget of the City of Cracow (self-government entity). Capital expenditures constitute a set of financial resources reflecting a state of the potential of the City budget to finance broadly defined development projects such as cataloged actions in the Strategy. Forecast values are based on the Multi-annual Financial Forecast of Cracow for the years of 2016-2052 (MFF). The amount takes into account the allowable amount of statutory debt ratios.

In parallel to the projection MFF, an attempt of analysis was made to determine the forecast of trends in shaping the future course of capital expenditures of the City. For this purpose, methods of extrapolation of development trends was used by authors of the article, that allows to build a predictive model using the observed trends in local finances [Markowska, Sobczak, 2006: 275]. Among the assumptions of the model was the level of total budget expenditure and the share of capital in the total income of Cracow which will show a trend similar to that of the period 1999-2016. The construction of the model is based, therefore, 
on correlating two forecasts of total expenditures and the percentage of capital expenditure of the total. The product of two projections set the level of possible capital expenditure, while maintaining the current trends.

\section{B. The National Budget}

The methodology for estimating the potential of the National Budget is based on two approaches: First, the analysis of the Annex to the Budget Bill for 2016 Summary of multiannual programs, which allowed the estimation of the amount of subsidizing investments in Cracow until 2019 (max. possible horizon) - these calculations resulted from the sum of the amounts included in the Bill. Secondly, the extrapolation forecast for the years of 2020-2030, were made by article authors. To build a predictive model based on data from the years 2001-2019, which for the period 2001-2015 came from a set of reports of budgets, and 2016-2019 with the Annex to the Budget Bill for 2016 Summary of multiannual programs. In framework to these documents for each of the years a sum of investments in Cracow by different entities (public sector and private) was made.

\section{EU Funds}

Methods of estimating the amount of EU funds was to respect the average share (2011-2014) of co-financing of investments in Cracow to the total amount of EU funds for the country in the period (2007-2013). The fact that the calculated average is a measure of the activity of the individual in obtaining EU funds was widely accepted. Thus, the amount of the share has become a multiplier of the amount of EU funds in 2014-2020 perspective (including the $\mathrm{n}+3$ principle). Due to the lack of knowledge about the next EU perspective (after 2020), estimates are presented only for the current time (2014-2020). These projections were the author's own calculations.

\section{Other public external sources}

Other public sources are different than the National Budget and EU funds - public sources of financing development projects in Cracow. In this group funding is: under the regional self-government and the budget of governor, as well as special purpose funds. Funding concerns both investments by the local government and private sector initiatives as well as universities, hospitals, etc. It is therefore a set of complementary funding sources listed above. The methodology is based on the determination of the forecast capital expenditure budgets managed by the Marshal's Office and the Governor's Office, which is based on the analysis of the documentation of both offices since 2001 (MFF, reports of budgets) and the assessment of the forecast using extrapolation methods by authors. Then, based on the mentioned historical documentation, the calculated average levels of the share of investments relating to Cracow, which became the basis of indicators used to the correction of extrapolation. The calculated amount was increased by co-financing of the investment forecast of special purpose funds, which has been developed on the basis of the average share of these sources to the value of Cracow's investments. 


\section{E. Private sector investments}

The methodology is based on the forecast of investment companies established in Cracow, which expanded to sales in the construction industry. Taking into account the sale of the building due to two reasons: (1) the important role of construction investment for the development of Cracow; (2) by the Law on Income Tax and the Law on Accounting, construction carried out by a construction company is not an investment, but a production. Reported estimates were input data for various functions of extrapolative models made by the authors.

\section{The results of the estimation}

Table 1 presents the amount of funding necessary for the implementation of the project of CDS 2030. This is the result of estimates of the research task No. 1. The table includes amounts aggregated for Strategic Areas and Operational Objectives, which are the result of summing the estimated amount for the key actions.

Among the important observations from the research process within task 1 are worth further discussion. First, key actions (the highest level of detail of Strategy) were formulated at a high level of generality and vagueness. An additional difficulty was the lack of monitoring indicators (the current value and the target), and the lack of a timetable of implementation. These conditions significantly hindered the estimate of financial expenditures for the implementation of key actions. Given these conditions in the estimates assumed that the key actions will be implemented with the same intensity in each of the years of the Strategy and that their scope will be similar to the corresponding activities carried out in the past in Cracow (satisfactory similarities criterion). Second, selected key actions were repeated, i.e. a similar statement of the key action occurred in different operational objectives. Implementation of such a strategy causes the risk of multi-financing of the same actions. The presented estimates did not accrue multiple similar-sounding key actions.

Table 2 presents the financial potential possible to engage in actions to achieve the objectives of the project of CDS 2030 or the results of the research task No. 2. The analysis of the table can be presented through the prism of amount descriptions in subsequent rows, i.e.:

- The Budget of the City of Cracow - the amounts are presented in variants. The first amount results from the findings of MFF. The second amount is the author's forecast and is explained in the methodology. In the case of the second estimation, the construction of a model is based on the correlating of two forecasts: total expenditure and the percentage of capital expenditure in the total expenditure.

The first forecast - total expenditure - was characterized by a very high degree of convergence of the model to empirical data (coefficient of determination $=0.97$ ), and the projected average annual increase in expenditures was 3.9\% for 2023 and $3.2 \%$ in the period 2024-2030. These values are close to the current Guidelines on macroeconomic assumptions for the needs of long-term financial forecasts of 
local government units (October 2015), in which the average annual increase in GDP of the country in analogical time is $3.7 \%$ and $3.0 \%$.

Table 1

The amount of financial expenditures in a strategic and operational objectives (current prices; exchange rates in 2016: $1 \mathrm{EUR}=4,4127 \mathrm{PLN}$; $1 \mathrm{USD}=4,2260$ PLN)

\begin{tabular}{|c|c|}
\hline Strategic and operational objectives & $\begin{array}{c}\text { Financial } \\
\text { expenditures } \\
\text { (mln PLN) }\end{array}$ \\
\hline $\begin{array}{l}\text { Strategic objective I: Cracow - open and harmonious metropolis of internatio- } \\
\text { nal importance in the areas of: innovation, science, economy and culture }\end{array}$ & 2808 \\
\hline I.1. Cracow - node in the network of Polish, European and World metropolises & 2200 \\
\hline I.2. Coordinated use of the potential of the Cracow Metropolitan Area & 607 \\
\hline $\begin{array}{l}\text { Strategic objective II: Cracow - the city which creates and effectively uses } \\
\text { the economic and scientific resources }\end{array}$ & 706 \\
\hline $\begin{array}{l}\text { II.1. Cooperation of science, business and local government for the development } \\
\text { of the City/Metropolis }\end{array}$ & 87 \\
\hline $\begin{array}{l}\text { II.2. Modern education systems adapted to the rapidly changing economy and } \\
\text { the labor market }\end{array}$ & 330 \\
\hline II.3. Supporting enterprise innovation & 289 \\
\hline $\begin{array}{l}\text { Strategic objective III: Cracow - the city which creates and feeds from } \\
\text { the cultural potential for developing of a modern metropolis }\end{array}$ & 1263 \\
\hline III.1. Diverse cultural offer & 1182 \\
\hline III.2. The high cultural competence of residents & 13 \\
\hline III.3. Efficient system of management of culture and its resources & 68 \\
\hline Strategic objective IV: Cracow - the city friendly to reside in & 5263 \\
\hline IV.1. Widely available, high-quality public space & 696 \\
\hline IV.2. Ecologically sustainable environment & 407 \\
\hline IV.3. Eco-friendly and efficient transport system & 3522 \\
\hline IV.4. Revitalized urban areas & 334 \\
\hline IV.5. The high degree sense of security in Cracow & 210 \\
\hline IV.6. The universal implementation of the idea of a healthy and active life & 93 \\
\hline $\begin{array}{l}\text { Strategic objective V: Cracow - strong local government community of resi- } \\
\text { dents of Cracow }\end{array}$ & 413 \\
\hline V.1. The high level of public and civic participation of residents & 147 \\
\hline V.2. A strong sector of social organizations (NGOs) & 94 \\
\hline V.3. Social cohesion & 172 \\
\hline Strategic objective VI: Cracow - modern managed metropolis & 502 \\
\hline VI.1. Friendly and efficient administration & 130 \\
\hline VI.2. The high quality of the strategic management of the city & 282 \\
\hline VI.3. Rational policy of the City in the area of spatial resources & 90 \\
\hline Grand total: & 10955 \\
\hline
\end{tabular}

Source: own calculations on the basis of: the City of Cracow, the Ministry of Finance, the Central Statistical Office 
Financial potential for the project of CDS 2030

\begin{tabular}{|l|l|l|l|l|}
\hline \multirow{2}{*}{\multicolumn{1}{|c}{ Funding Sources }} & \multicolumn{1}{|c|}{$\mathbf{2 0 1 7 - 2 0 2 3}$} & \multicolumn{2}{c|}{ 2024-2030 } & \multicolumn{2}{c|}{ Sum } \\
\cline { 2 - 5 } & \multicolumn{3}{|c|}{ (mln PLN, current prices) } \\
\hline 1. The Budget of the City of Cracow & $4138-5655$ & $4485-6857$ & $8623-12512$ \\
\hline 2. The National Budget & 1710 & 2328 & 4038 \\
\hline 3. EU funds, including: & 5779 & 0 & 5779 \\
\hline Public investment of the City of Cracow & 1271 & 0 & 1271 \\
\hline Investment of companies in Cracow & 2889 & 0 & 2889 \\
\hline Investments other public entities & 1618 & 0 & 1618 \\
\hline 4. Other public external sources & 216 & 205 & 420 \\
\hline 5. Private sector investments & 69841 & 77554 & 147395 \\
\hline Investments industry and construction & 52368 & 59681 & 112049 \\
\hline Housing market & 23684 & 12445 & 36129 \\
\hline Office market & 21256 & 43521 & 64777 \\
\hline & & Grand total: & $166255-170141$ \\
\hline
\end{tabular}

Source: own calculations on the basis of: the City of Cracow, the Ministry of Finance, the Central Statistical Office, the Office of the Marshal of the Małopolska Region, the Małopolska Governor Office in Cracow

The second forecast - the share of capital expenditure - pointed to a stable share of capital expenditure in the structure of the budget - the average level of $15.1 \%$ (standard deviation $=0.004$ ). The product of two projections set the level of possible capital expenditure, while maintaining the current trends. It should be added that projected above values of capital expenditures are characterized by cautious, average annual growth of $3.1 \%$ for 2023 and $2.6 \%$ in the period $2024-2030$. The author's forecast of the mentioned capital expenditures was further verified in terms of the level of debt. That verification of the level of debt was based on forecasting the size of the debt resulting from the extrapolation forecast. Estimating the size of the debt was based on the accumulation of the City's debt to the sum of the differences between forecast expenditures in property, and operating surplus. At the same time the value of the debt was increased by interest on debt resulting from MFF in the same period. As a result, these estimates of the amount in the extrapolation forecast point to the possibility of additional debt (more than forecasted in MFF).

Summarizing the above, a formula can be forecasted of capital expenditure trends set by the presented predictive model, signalizing the possibility of funding for new (excluded from MFF) development activities. 
- The National Budget - co-financing applies to the initiatives of the private sector, universities, hospitals, etc. It is therefore a broad set of investments in the City, which fit in with the objectives of the Strategy. The predictive model characterized by an adequate level of convergence (coefficient of determination $=0.8$ ). The presented forecast assumes an average annual increase in the value of co-financing of $7 \%$ for 2023 . And $4 \%$ in the period 2023-2030. With regard to the dynamics in the period 2001-2016 referring to investments in Cracow from the National Budget, it can be indicated that the presented forecast is cautious, because in this period the average annual increase was $10.5 \%$.

- $\quad$ EU funds - reported amounts indicate the potential amount of funding the activities carried out by various entities (private, public) in Cracow from EU funds. Projected estimates associated with current trends (2011-2014) in funding of investments in Cracow. Item No. 3 in the table also presents the level of EU co-financing for investments not only of the City of Cracow but also private companies and other public entities.

- Other public external sources - reported amounts include potential other than the National Budget and EU funds - public financing sources of development projects in Cracow. This group includes: investment co-financing under the regional self-government and the budget of the governor, as well as special purpose funds. Funding concerns both investments by the local self-government and private sector initiatives as well as universities, hospitals, etc. It is therefore a set of complementary sources of financing item 2. and 3. of the attached table. The forecast assumes the reduction of investment financing in Cracow from analyzed sources in the period 2017-2023 by an average of 7.7\% per year. This results among others, from the financial policy of the Marshal's Office that assumes a reduction of capital expenditure (Marshal's Office MFF) and a projected decline in capital expenditure of the Governor's Office. However, in the period 2024-2030 the forecast model assumes a stabilization at a relatively low level, and the average annual increase in the amount of funds will be $3.4 \%$ per year (the national's GDP growth of 3.0\%).

- Private sector investments - forecasting models assume an average annual increase in the value of the investment potential of $1.8 \%$ in the period 2017-2023 and 1.3\% in 2023-2030. In particular regard to the property market, the forecasting model involves structural change: currently dominates sales of housing, which will gradually decrease, for growth and advantages of business office investments. The predictive model confirms the ongoing trends and mechanisms of spatial development of metropolitan areas in the City core. As for increasing the role of the core city in the business sphere, with the simultaneous processes of residential suburbanization. Therefore, the predictive model explains the significant increase 
in business space in Cracow. The negative dynamics of the new residential area in Cracow due to the combination of the processes of suburbanization while satisfying the housing needs of residents through primary and secondary markets.

\section{Conclusions}

The objective of conceptualization and operationalization of the method of estimating the financial implications of planning decisions was implemented on the example of the CDS 2030 project and presented in this article. Therefore, the conclusion can be summed up in three main groups, i.e. inferences: conceptual, operationalizational, exemplificational.

Among the most important conceptual inferences, one could mention the complexity of estimating the financial implications of planning decisions. This complexity is seen in detail and concreteness of actions included in the plans, yet rather realistically the lack there of the concreteness of actions. Lack of clarity in defining action strategies particularly those with the most detailed character, significantly restricts the use of specific techniques for estimating expenditures of their implementation. This problem is led by the long time horizon of implementation of actions (several years) in which the implementation of these changes is noted- these are particular to the multiplier effects and synergies triggered by the implementation of the strategy.

With regard to the operationalizational inferences of the methodology attention needs to be brought to two fundamental issues. The first refers to the resource of financial data underlying the estimates. Since most detailed action of strategies are formulated vaguely, the techniques of desk research and analog forecasting plays an important role in their estimation. These techniques require extensive collection of reports documenting the expenditure for the implementation of actions similar in character to the estimation (e.g. evaluations, reports on the implementation of development programs, etc.). Given these circumstances, one cannot overestimate the Internet archives of public offices which aggregate such documents, especially in terms of wealth and quality of these archives. The second refers to one of the possible econometric techniques to use for estimating. As for the extrapolation of development trends method which in simple forecast projected an average of the phenomenon. These methods are often criticized for their inaccuracy due to an average value, and not an exact value of the future. However, the case of forecasting the financial implications of long-term plans has at least two important features: (1) is counteracted weakness of the forecasting average, because those projected annual average values are summed in an amount representing the value of the action in the horizon of the strategy; (2) account is taken of the wider trend of the phenomenon, which takes into account: organizational behavior in public and private entities, the direction of socio-economic, inflation, etc. 
However, in respect to the exemplificational inferences one should identify those that relate to assess ex-ante investment expenditures for the project CDS, i.e.: (1) confirmed the conceptual problem of complexity estimates planning decisions. In the case of CDS, it relies on the key actions (highest level of detail) have been formulated as very general and vague. In addition, there was a lack of monitoring indicators (the current value and the target), and the lack of a timetable of implementation; (2) The selected key actions in the document are duplicated on their merits. The implementation of such a planned strategy raises a danger of multi-financing the same actions; (3) Investments into CDS will reach 11 billion PLN, while the financial potential of the local authorities who are actually able to reach oscillates around 16 billion PLN. Therefore it can be assumed that the proposed strategy has financial coverage in a variety of financial sources.

\section{Bibliography}

Hołuj A., Hołuj D. (2010), Programowanie rozwoju miasta Krakowa na przykładzie wybranych dokumentów strategicznych i operacyjnych, Zeszyty Naukowe, 821, Uniwersytet Ekonomiczny w Krakowie, p. 61-77.

Markowska M., Sobczak E. (2006), Przeglad wybranych metod oceny rozwoju regionalnego [w:] D. Strahl (red.), Metody oceny rozwoju regionalnego, Wydawnictwo Akademii Ekonomicznej we Wrocławiu, Wrocław.

Strategia Rozwoju Krakowa 2030 (2016), Urząd Miasta Krakowa - version of May 2016.

Wytyczne dotyczacym założeń makroekonomicznych na potrzeby wieloletnich prognoz finansowych jednostek samorzadu terytorialnego (2015), Ministerstwo Finansów.

Wieloletnia Prognoza Finansowa Miasta Krakowa na lata 2016-2052 (WPF) (2016), Urząd Miasta Krakowa.

Zestawienie programów wieloletnich - Ustawa Budżetowej na rok 2016 (2016), Ministerstwo Finansów.

Wieloletnia Prognoza Finansowa (2016), Urząd Marszałkowski Województwa Małopolskiego. 